\title{
Blood Lipid Components and SREBP-1 Gene Expression in Broiler Chickens Fed Different Dietary Lipid Sources
}

\author{
Amir Moslehi', Ali Asghar Sadeghi' ${ }^{1}$, Parvin Shawrang' ${ }^{2}$ \& Mehdi Aminafshar ${ }^{1}$
}

\begin{abstract}
Background: Liver plays an important role in energy homeostasis. Intense liver diseases are accompanied with lower concentrations of n-3 and n-6 poly unsaturated fatty acids (PUFA). It has been found that $n-3$ PUFA play importantly protective roles in the liver. There was limited information about the effects of lipid sources on serum lipid components and liver sterol regulatory element binding-1 (SREBP-1) gene expression. Therefore, the aim of this study was to evaluate and compare the effects of fish oil, corn oil, olive oil and tallow, respectively, as dietary sources of n-3, n-6, n-9 and saturated fatty acid on serum lipid compound and liver SREBP-1 gene expression in broiler chicks.

Materials, Methods \& Results: In a completely randomized design, 240 one-day-old broiler chicks were allocated to five dietary treatments, four replicates and 12 chicks per each. Dietary treatments included of: control (diet without lipid supplementation) and diet supplemented with fish oil as a n-3 fatty acid source, corn oil as a n-6 fatty acid source, olive oil as a n-9 fatty acid source and tallow as a saturated fatty acid which were added to diets at $1.5,3$ and $4 \%$ in the starter, grower and finisher, respectively. At days 28 and 42 of age, liver tissue was dissected out and samples were placed in liquid nitrogen, also blood samples were collected. The SREBP-1 mRNA expression in liver tissue was quantitated using RT-PCR. Broilers fed diets containing fish oil, corn oil and olive oil as unsaturated fatty acid sources had lower concentrations of triacylglycerol than those fed other diets. Also, diets containing fish oil and tallow showed the lowest low density lipoprotein (LDL) levels at day 28 of age. Diets containing corn oil and olive oil showed higher levels of cholesterol and high density lipoprotein (HDL) than other diets but, these differences were not significant at days 28 and 42 of age $(P \geq 0.05)$. In both sampling periods, the chickens fed diets containing tallow expressed higher $(P<0.05)$ SREBP-1 gene as compared to those fed other dietary lipids. Broilers fed diet containing corn oil had higher $(P<0.05)$ SREBP-1 gene expression than those fed diet containing fish oil and olive oil.

Discussion: Serum lipids were affected by dietary fat source. Lower concentration of serum triacylglycerols was found in broilers fed fish oil and corn oil diets as dietary n-3 and n- 6 fatty acid sources. It was shown that dietary PUFA, especially n-6 and n-3 fatty acids could reduce hepatic fatty acid and triacylglycerol synthesis. Broilers fed corn oil diet showed elevated LDL levels respect with those fed fish oil or tallow at day 28 of age. The results showed that dietary polyunsaturated fatty acids and saturated fatty acids substantially affected on SREBP-1 gene expression at days 28 and 42 of age. The birds fed fish oil as n-3 PUFA source expressed lower SREBP-1 gene compared with other groups at day 28 of age. Longer chain length, high number of double bonds, and the presence of the first double bond gives these fatty acids distinct and unique properties that separate them and their metabolic products from the more common n- 6 and n- 9 fatty acids. The finding of this study indicated lipogenic effects of tallow and then corn oil. The results confirmed that each of dietary lipid sources had different effect on serum lipid components. It was also found that SREBP-1 gene expression is age-dependent and it increased as age of broilers increased.
\end{abstract}

Keywords: broiler chicks, lipid type, gene expression, tallow, serum lipid components. 


\section{INTRODUCTION}

Liver plays an important role in energy homeostasis. Intense liver diseases are accompanied with lower concentrations of $n-3$ and $n-6$ poly unsaturated fatty acids (PUFA). It has been found that n-3 PUFA play importantly protective roles in the liver. Researchers have reported that dietary supplementation with fish oil (rich of n-3 PUFA) has nutritional advantages [5,32]. A complete depletion of long chain n-3 fatty acids has been observed in cardiac and liver of birds dying from sudden death syndrome [2,8]. Various studies suggest that in both birds and mammals, PUFA inhibit lipid synthesis [28,31], elevate fatty acid oxidation [26] and diet-induced thermogenesis [10] and minimize reduced growth rates by preventing the catabolic effects of immune stimulation [11]. Lipid sources added to broiler diets can modify the concentrations of triacylglycerols and lipoproteins in blood [19].

Sterol Regulatory Element Binding-1 (SREBP-1) is a transcription factor that stimulates the expression of lipogenic and cholesterol biosynthesis [34]. In rodents and pigs fed fish oil, the content of hepatic fatty acid synthase decreased by suppression of SREBP-1 expression [4, 12]. The SREBP-1 gene expression have been mainly evaluated oin mammalian species especially rodents, but researches in the birds, especially broiler chicks are rare. Therefore, this study was conducted to evaluate the effect of lipid sources containing n-3, n-6 and n-9 fatty acids on blood lipid compound and SREBP-1gene expression in broiler chicks.

\section{MATERIALS AND METHODS}

\section{Animal and diets}

A total of 240 one-day-old broiler chicks (Ross 308) was purchased from a commercial hatchery and used in a 42 days feeding trial. In a completely randomized design, chicks were divided into 5 treatments (control and four lipid sources) with 4 replicates and 12 chicks per each. Treatments included of free lipid diet as control group and 4 different levels of dietary lipids comprised of fish oil as a n-3 fatty acid source, corn oil as a n- 6 fatty acid source, olive oil as a n-9 fatty acid source and tallow as a saturated fatty acid which were added to diets as $1.5,3$ and $4 \%$ in the starter, grower and finisher, respectively. Control diet had no supplemental dietary lipid and energy content was supplied by including pure starch (Tables 1 and 2). Throughout the study, chicks accessed to feed and water ad libitum. Lighting schedule were 23L/1D, while the temperature was gradually reduced $3^{\circ} \mathrm{C}$ from initially $32^{\circ} \mathrm{C}$ in each week.

\section{Lipid analysis}

Lipid from diet samples were extracted using a Folch wash of chloroform/ methanol (2:1, v/v). Methyl esters of fatty acids (FAME) in lipid extracts were prepared by transestrification using $2 \mathrm{~mL}$ of Heptane and $2 \mathrm{~mL}$ of $2 \mathrm{M} \mathrm{KOH}-\mathrm{MeOH}$ were added to the lipids, and the samples were vortex-mixed and heated at $70^{\circ} \mathrm{C}$ for $10 \mathrm{~min}$. The FAME were separated using a $60 \mathrm{~m} \times 0.25$ mm i.d., $0.2 \mu \mathrm{m}$ film thickness; TR-CN 100 column $^{1}$ and analyzed using a gas-liquid chromatograph ${ }^{2}$ with a flame ionization detector and ultra-pure hydrogen as the carrier gas at a flow rate of $10 \mathrm{ml} / \mathrm{min}$. Conditions for analysis of dietary lipid extracts were: spilt injection (50:1), $0.1 \mu \mathrm{L}$ injection volume, initial oven temperature $150^{\circ} \mathrm{C}$ (held for $5 \mathrm{~min}$ ), increased to $175^{\circ} \mathrm{C}$ at a rate of $5^{\circ} \mathrm{C} / \mathrm{min}$ and held for $10 \mathrm{~min}$, increased to $190^{\circ} \mathrm{C}$ at a rate of $10^{\circ} \mathrm{C} / \mathrm{min}$ and held for $20 \mathrm{~min}$. Injector and detector temperatures were held at $250^{\circ} \mathrm{C}$ and $280^{\circ} \mathrm{C}$, respectively. The peak of fatty acids were identified and quantified by comparison with the retention time and peak area of each fatty acid standard. Fatty acid content was expressed as the percentage of total fatty acids. The amounts of total saturated fatty acids (SFA), monounsaturated fatty acids (MUFA), polyunsaturated fatty acids (PUFA), total (n-3) and (n-6) PUFA, as well as the $(n-6) /(n-3)$ ratios were calculated from the gasliquid chromatographic analysis.

\section{Blood and liver tissue sampling}

At days 28 and 42 of age, 8 chicks were randomly selected from each treatment ( 2 chicks per replicate) after an overnight fast, weighed and blood samples were obtained from wing veins and then killed by cervical dislocation. Blood samples were allowed to clot at $4^{\circ} \mathrm{C}$ for $2 \mathrm{~h}$ and then centrifuged at $1500 \times$ $g$ for $15 \mathrm{~min}$ and serum was separated and stored at $-20^{\circ} \mathrm{C}$ until lipid compound analysis. The liver tissue was immediately dissected out and stored in a freezer $-70^{\circ} \mathrm{C}$ until analyzed for SREBP-1 gene expression.

\section{Measurement of serum lipid compound}

Lipid compound in serum samples were determined using triacylglycerol, cholesterol, LDL and 
HDL kits ${ }^{3}$ and an automatic biochemical analyzer ${ }^{4}$ using colorimetric method was used $505 \mathrm{~nm}, 505 \mathrm{~nm}$, $600 \mathrm{~nm}$ and $650 \mathrm{~nm}$ wave lengths for triacylglycerol, cholesterol, LDL and HDL, respectively.

\section{RNA isolation and reverse transcription}

Total RNA was extracted from the chicken liver tissue using the Trizol reagent. The concentration and quality of extraction RNA were evaluated for each sample by using both UV absorbances (260/280) in addition to $1 \%$ agarose gel electrophoresis. For estimation of RNA quantity was used nanodrop apparatus ${ }^{5}$. Then, RNA samples were stored at $-80^{\circ} \mathrm{C}$ until use. RNA was treated with DNase using Ambions DNA-free $\mathrm{kit}^{6}$ to eliminate any possible DNA impurity. Samples were conserved at $-80{ }^{\circ} \mathrm{C}$ until use. For optimization of Reverse and forward primers concentrations was used three different quantity for each of primers and ultimately optimized concentration was achieved for SREBP-1 and housekeeping gene primers as are shown in Table 3.

Reverse Transcription (RT) PCR was carried out using RT-PCR kit ${ }^{7}$ containing RNA $(5 \mu \mathrm{g}), 1200$ $\mathrm{nM}$ of gene specific primer and $2 \mu \mathrm{L}$ diethylpyrocarbonate-treated water. The mixture was incubated at $65{ }^{\circ} \mathrm{C}$ for $5 \mathrm{~min}$, then $2 \mu \mathrm{L}$ buffer RT enzyme, $1 \mu \mathrm{l}$ deoxy nucleoside triphosphate mix, and $400 \mathrm{U} / \mu \mathrm{L}$ of MMuLV Reverse Transcriptase ${ }^{6}$ were added to the above mixture. After incubation $\left(42^{\circ} \mathrm{C}, 30 \mathrm{~min}\right)$, the mixture was heated $\left(85^{\circ} \mathrm{C}, 5 \mathrm{~min}\right)$ and then temperature was decreased to $4^{\circ} \mathrm{C}$ and synthesized cDNA were quickly placed at $-20^{\circ} \mathrm{C}$. Chicken SREBP-1 primer sequences were designed by oligo 7 software and $18 \mathrm{~S}$ rRNA primers as an internal control gene that showed in Table 4.

Table 1. Ingredients and nutrient compositions of experimental diets in grower (day 11 to day 28).

\begin{tabular}{|c|c|c|c|c|c|}
\hline Ingredient (\%) & Control & Fish oil & Corn oil & Olive oil & Tallow \\
\hline Corn & 51.70 & 55.44 & 55.44 & 55.44 & 55.44 \\
\hline Soybean Meal (46\% CP) & 27.40 & 31.70 & 31.70 & 31.70 & 31.70 \\
\hline Starch & 8.70 & 0.00 & 0.00 & 0.00 & 0.74 \\
\hline Fish oil & 0.00 & 3.00 & 0.00 & 0.00 & 0.00 \\
\hline Corn oil & 0.00 & 0.00 & 3.00 & 0.00 & 0.00 \\
\hline Olive oil & 0.00 & 0.00 & 0.00 & 3.00 & 0.00 \\
\hline Tallow & 0.00 & 0.00 & 0.00 & 0.00 & 3.00 \\
\hline Corn Gluten & 8.00 & 4.00 & 4.00 & 4.00 & 4.00 \\
\hline Calcium Carbonate & 1.10 & 1.10 & 1.10 & 1.10 & 1.10 \\
\hline Di Calcium Phosphate & 1.75 & 1.75 & 1.75 & 1.75 & 1.75 \\
\hline Sodium Chloride & 0.33 & 0.33 & 0.33 & 0.33 & 0.33 \\
\hline DL-methionine & 0.28 & 0.28 & 0.28 & 0.28 & 0.28 \\
\hline Vitamin and Mineral Premix* & 0.50 & 0.50 & 0.50 & 0.50 & 0.50 \\
\hline L-Lysine & 0.25 & 0.25 & 0.25 & 0.25 & 0.25 \\
\hline Zeolite & 0.00 & 1.60 & 1.60 & 1.60 & 0.90 \\
\hline \multicolumn{6}{|l|}{ Nutrient Compositions (\%) } \\
\hline AME (kcal/kg) & 3,050 & 3,050 & 3,050 & 3,050 & 3,050 \\
\hline Crude protein & 21.01 & 21.00 & 21.00 & 21.00 & 21.00 \\
\hline Crude Fat & 3.91 & 7.18 & 7.18 & 7.18 & 7.18 \\
\hline Lysine & 1.15 & 1.24 & 1.24 & 1.24 & 1.24 \\
\hline Methionine & 0.62 & 0.60 & 0.60 & 0.60 & 0.60 \\
\hline Methionine plus Cystine & 0.98 & 0.95 & 0.95 & 0.95 & 0.95 \\
\hline \multicolumn{6}{|l|}{ Fatty acids (\%) } \\
\hline C18:1 n-9 & 1.03 & 1.99 & 1.99 & 3.32 & 2.14 \\
\hline C18:2 n-6 & 2.05 & 2.25 & 3.81 & 2.46 & 2.31 \\
\hline C18:3 n-3 & 0.09 & 0.15 & 0.13 & 0.12 & 0.13 \\
\hline$(n-6) /(n-3)$ & 22.77 & 15.00 & 29.30 & 20.05 & 17.76 \\
\hline
\end{tabular}

*Vitamin and mineral provided per kilogram of diet: vitamin A, $360000 \mathrm{IU}$; vitamin D3, $800000 \mathrm{IU}$; vitamin E, 7200 IU; vitamin K3, $800 \mathrm{mg}$; vitamin B1, $720 \mathrm{mg}$; vitamin B9, $400 \mathrm{mg}$; vitamin H2, $40 \mathrm{mg}$; vitamin B2, $2640 \mathrm{mg}$, vitamin B3, $4000 \mathrm{mg}$; vitamin B5, $12000 \mathrm{mg}$; vitamin B6, 1200 mg; vitamin B12, 6 mg; Choline chloride, 200000 mg, Manganese; 40000 mg; Iron, 20000 mg; Zinc, 40000 mg; Copper, 4000 mg; Iodine, 400 mg. 
A. Moslehi, A.A. Sadeghi, P. Shawrang \& M. Aminafshar. 2016. Blood Lipid Components and SREBP-1 Gene Expression in Broiler Chickens Fed Different Dietary Lipid Sources.

Table 2. Ingredients and nutrient composition of experimental diets in finisher (day 29 to day 42 ).

\begin{tabular}{|c|c|c|c|c|c|}
\hline Ingredient $(\%)$ & Control & Fish oil & Corn oil & Olive oil & Tallow \\
\hline Corn & 56.50 & 59.90 & 59.90 & 59.90 & 59.90 \\
\hline Soybean Meal (46\% CP) & 19.00 & 29.20 & 29.20 & 29.20 & 29.20 \\
\hline Starch & 9.86 & 0.00 & 0.00 & 0.00 & 1.00 \\
\hline Fish oil & 0.00 & 4.00 & 0.00 & 0.00 & 0.00 \\
\hline Corn oil & 0.00 & 0.00 & 4.00 & 0.00 & 0.00 \\
\hline Olive oil & 0.00 & 0.00 & 0.00 & 4.00 & 0.00 \\
\hline Tallow & 0.00 & 0.00 & 0.00 & 0.00 & 4.00 \\
\hline Corn Gluten & 10.60 & 1.90 & 1.90 & 1.90 & 1.90 \\
\hline Calcium Carbonate & 1.03 & 1.04 & 1.04 & 1.04 & 1.04 \\
\hline Di Calcium Phosphate & 1.70 & 1.60 & 1.60 & 1.60 & 1.60 \\
\hline Sodium Chloride & 0.35 & 0.33 & 0.33 & 0.33 & 0.33 \\
\hline DL-methionine & 0.19 & 0.26 & 0.26 & 0.26 & 0.26 \\
\hline Vitamin and Mineral Premix* & 0.50 & 0.50 & 0.50 & 0.50 & 0.50 \\
\hline L-Lysine & 0.41 & 0.15 & 0.15 & 0.15 & 0.15 \\
\hline Zeolite & 0.00 & 1.10 & 1.10 & 1.10 & 0.12 \\
\hline \multicolumn{6}{|l|}{ Nutrient Compositions (\%) } \\
\hline $\operatorname{AME}(\mathrm{kcal} / \mathrm{kg})$ & 3,150 & 3,150 & 3,150 & 3,150 & 3,150 \\
\hline Crude protein & 19.00 & 19.00 & 19.00 & 19.00 & 19.00 \\
\hline Crude Fat & 3.94 & 8.30 & 8.30 & 8.30 & 8.30 \\
\hline Lysine & 1.09 & 1.09 & 1.09 & 1.09 & 1.09 \\
\hline Methionine & 0.53 & 0.55 & 0.55 & 0.55 & 0.55 \\
\hline Methionine plus Cystine & 0.86 & 0.86 & 0.86 & 0.86 & 0.86 \\
\hline \multicolumn{6}{|l|}{ Fatty acids $(\%)$} \\
\hline C18:1 n-9 & 1.05 & 2.34 & 2.33 & 4.11 & 2.53 \\
\hline C18:2 n-6 & 2.09 & 2.34 & 4.41 & 2.63 & 2.41 \\
\hline C18:3 n-3 & 0.07 & 0.16 & 0.13 & 0.12 & 0.13 \\
\hline$(n-6) /(n-3)$ & 29.85 & 14.62 & 33.92 & 21.91 & 18.53 \\
\hline
\end{tabular}

*Vitamin and mineral provided per kilogram of diet: vitamin A, 360000 IU; vitamin D3, 800000 IU; vitamin E, 7200 IU; vitamin K3, 800 mg; vitamin B1, $720 \mathrm{mg}$; vitamin B9, $400 \mathrm{mg}$; vitamin $\mathrm{H2}, 40 \mathrm{mg}$; vitamin B2, $2640 \mathrm{mg}$, vitamin B3, $4000 \mathrm{mg}$; vitamin B5, $12000 \mathrm{mg}$; vitamin B6, 1200 mg; vitamin B12, 6 mg; Choline chloride, 200000 mg, Manganese; 40000 mg; Iron, 20000 mg; Zinc, 40000 mg; Copper, 4000 mg; Iodine, 400 mg.

Table 3. Optimized primer concentrations.

\begin{tabular}{cccc}
\hline & \multicolumn{3}{c}{ Forward Primer $(\mathrm{nM})$} \\
\hline Reverse Primer $(\mathrm{nM})$ & 50 & 300 & 900 \\
50 & $50 / 50$ & $50 / 300$ & $50 / 900$ \\
300 & $50 / 300$ & $300 / 300$ & $300 / 900$ \\
900 & $50 / 900$ & $300 / 900$ & $900 / 900$ \\
\hline
\end{tabular}


Table 4. Oligonucleotide primer sequences for RT-PCR amplification.

\begin{tabular}{ccc}
\hline Primer & Sequence & Product Size (bp) \\
\hline SREBP-1 & 5/ - CTACCGCTCATCCATCAACG -3/ & 145 \\
Forward & $5 /-$ CTGCTTCAGCTTCTGGTTGC -3/ & \\
Reverse & & 148 \\
\hline 18 S rRNA & 5/ - CGCGTGCATTTATCAGACCA-3/ & \\
\hline Forward & 5/ - ACCCGTGGTCACCATGGTA - 3/ \\
\hline Reverse
\end{tabular}

Liver mRNA quantitation by Real-Time RT-PCR

A master mix containing SYBR Green PCR master mix $^{8} 900 \mathrm{nM}$ of forward primer, $900 \mathrm{nM}$ of reverse primer, cDNA and water was prepared to perform real-time PCR. The following PCR protocol was used on the PCR ABI step-one apparatus ${ }^{8}$. Initial steps were $5 \mathrm{~min}$ at $95^{\circ} \mathrm{C}$, followed by a 3-step amplification program $\left(95^{\circ} \mathrm{C}\right.$ at $30 \mathrm{~s}$ followed by $55^{\circ} \mathrm{C}$ at $30 \mathrm{~s}$ and final step was $72^{\circ} \mathrm{C}$ at $30 \mathrm{~s}$ ) repeated 40 times. Quantification was performed using step-one software 2.2. The 18s RNA was considered as a house keeping. Each PCR run included a no-template control and replicates of control and unknown samples. Runs were performed in duplicate at the end of each run to control for amplification specificity; a melt curve analysis was designed.

\section{Statistical analysis}

All analyses were subjected to analysis of variance procedures appropriate for a completely randomized design using the General Linear Model procedures of SAS Institute. Significant differences at $P<0.05$ statistical level compared by Duncan's multiple range tests.

\section{RESULTS}

\section{Blood Serum Metabolites}

Values for selected serum metabolites in bird fed the experimental diets are given in Table 5. Among whole of the assessed metabolites, triacylglycerol concentrations at both days 28 and 42 of age and LDL amounts at day 28 were only affect by fat sources $(P<0.05)$. Broilers fed diets containing fish oil, corn oil and olive oil as unsaturated fatty acid sources had lower concentrations of triacylglycerol than those fed other diets. Also, diets containing fish oil and tallow showed decreasing LDL levels at day 28 of age. Although, diets containing corn oil and olive oil showed higher levels of cholesterol and HDL than other diets but, this differences were not significant at days 28 and 42 of age $(P \geq 0.05)$.

\section{SREBP-1 gene expression}

The effects of supplemental lipid sources on SREBP-1 gene expression in liver are reported in Table 6. Sampling results at the end of the days 28 and 42 of age showed that the birds fed tallow as saturated fatty acid source had higher SREBP-1 gene expression compared with birds fed other diets $(P<0.05)$.

Table 5. Effect of dietary various lipid sources on serum lipid compound at days 28 and 42 of age (mg/dL).

\begin{tabular}{|c|c|c|c|c|c|c|c|c|}
\hline \multirow{2}{*}{ Treatments } & \multicolumn{2}{|c|}{ LDL } & \multicolumn{2}{|c|}{ HDL } & \multicolumn{2}{|c|}{ Cholesterol } & \multicolumn{2}{|c|}{ TG } \\
\hline & $28 \mathrm{~d}$ & $42 \mathrm{~d}$ & $28 \mathrm{~d}$ & $42 \mathrm{~d}$ & $28 \mathrm{~d}$ & $42 \mathrm{~d}$ & $28 \mathrm{~d}$ & $42 \mathrm{~d}$ \\
\hline Control & $62.4^{\mathrm{a}}$ & $40.0^{\mathrm{ab}}$ & 169 & 115 & 97.7 & 66.4 & $59.2^{\mathrm{ab}}$ & 36.3 \\
\hline Fish oil & $34.8^{\mathrm{ab}}$ & $22.4^{\mathrm{b}}$ & 143 & 119 & 83.7 & 68.9 & $46.2^{\mathrm{b}}$ & 41.5 \\
\hline Corn oil & $18.8^{\mathrm{b}}$ & $23.7^{\mathrm{b}}$ & 187 & 118 & 106.6 & 69.1 & $72.2^{\mathrm{a}}$ & 38.2 \\
\hline Olive oil & $19.6^{b}$ & $26.0^{\mathrm{ab}}$ & 171 & 123 & 100.6 & 75.8 & $54.0^{\mathrm{ab}}$ & 36.6 \\
\hline Tallow & $36.0^{\mathrm{ab}}$ & $52.4^{\mathrm{a}}$ & 145 & 100 & 86.6 & 59.5 & $45.8^{\mathrm{b}}$ & 28.5 \\
\hline SEM & 15.61 & 9.83 & 20.3 & 11.2 & 12.47 & 7.42 & 9.33 & 7.53 \\
\hline
\end{tabular}

a,b Means in the same columns with different letter are significantly different $(P \leq 0.05)$. 
Table 6. The relative quantification of SREBP-1 gene expression of broilers fed different fat source at days 28 and 42 of age.

\begin{tabular}{ccc}
\hline Treatments & \multicolumn{2}{c}{ Relative Quantitation } \\
\cline { 2 - 3 } & $28 \mathrm{~d}$ & $42 \mathrm{~d}$ \\
\hline Control & $1.000^{\mathrm{b}}$ & $1.000^{\mathrm{b}}$ \\
Fish oil & $0.0096^{\mathrm{d}}$ & $0.5861^{\mathrm{c}}$ \\
Corn oil & $0.0198^{\mathrm{c}}$ & $1.3266^{\mathrm{b}}$ \\
Olive oil & $0.0092^{\mathrm{d}}$ & $0.4723^{\mathrm{c}}$ \\
Tallow & $2.3980^{\mathrm{a}}$ & $24.1971^{\mathrm{a}}$ \\
\hline
\end{tabular}

a-d Means in the same columns with different letter are significantly different $(P \leq 0.05)$.

\section{DISCUSSION}

Serum lipids were affected by dietary fat source. Lower concentration of serum triacylglycerols was found in broilers fed Fish oil and Corn oil diets as dietary n-3 and n-6 fatty acid sources. Harris [17] showed that dietary PUFA, especially n- 6 and n-3 fatty acids may reduce hepatic fatty acid and triacylglycerol synthesis. In addition to, Legrand et al. [24] and Lochsen et al. [25] reported an inhibition of the activity of $\Delta 9$-desaturase, which leads to a limited triacylglycerol secretion from the liver to the blood, also, UFAs may show a higher rate of $\beta$-oxidation and as a result a higher rate of uptake of triacylglycerols from blood stream to tissue compared with SFA [31]. In recent studies, results have shown that model chylomicronsize and VLDL-size triacylglycerol-rich particles containing 5-48\% of their fatty acids as EPA and DHA (derivative of $\alpha$ Linolenic acid) compared with n-6 triacylglycerol-rich particles were cleared faster from blood in both humans and animals [29]. Broilers fed corn oil diet showed elevated LDL levels respect with those fed fish oil or tallow at day 28 of age. Hassan et al. [18] reported that LDL levels was positively correlated with cholesterol and also was negatively correlated with HDL, while in our study, this relation was only shown about cholesterol amounts at day 28 of age, although these amounts was not statistically significant. Fan et al. [13] found that diets containing different fat sources did not affect blood cholesterol values. In general, these results agree with the findings of other authors who reported changes in the concentration of serum lipids of chickens with the dietary fat sources differing in their degree of saturation $[6,30]$.

The current study results showed that dietary polyunsaturated fatty acids and saturated fatty acids substantially affected on SREBP-1 gene expression at days 28 and 42 of age. The birds fed fish oil as n-3 PUFA source expressed lower SREBP-1 gene com- pared with other groups at day 28 of age. Seo et al. [33] postulated that their longer chain length, high number of double bonds, and the presence of the first double bond ( 3 carbon atoms from the methyl terminal ,thus n-3) gives these fatty acids distinct and unique properties that separate them and their metabolic products from the more common n- 6 and n- 9 fatty acids. Various hypotheses about effectiveness of n-3 PUFA on gene expression through modulating cellular mechanism has been suggested by researchers. Kew et al. [22] reported that $\mathrm{n}-3$ acyl chain position within a triacylglycerol molecule apparently has a significant effect on the potency of n-3 fatty acids in regulating protein expression. In another study, PUFA alone significantly decreased transcriptionally active concentrations of SREBP-1 [35]. Worgall et al. [37] reported that longer chain PUFA, eg, EPA, DHA have far more inhibitory capacity on SREBP processing than do SFA have no or almost no effect on SREBP processing while results of our study was inconsistent to this finding due to broiler fed tallow as diet contained saturated fatty acids expressed much more SREBP-1 gene than other groups. Johnson et al. [21] with using large and small unilamellar vesicles as a model for plasma and intracellular membranes, showed that addition of fatty acids to these model membranes decreases the affinity of cholesterol for phospholipid and this causes enhanced transfer from cholesterol-rich regions to cholesterol-poor regions that would lead to ceased SREBP transport out of endoplasmic reticulum to the Golgi. The results of additional studies revealed that PUFAs can be effective on SREBP-1 gene expression by different ways: one, PUFA decreased SREBP expression by affecting the cellular composition of membranes. PUFAs accelerate the hydrolysis of plasma membrane sphingomyelin to ceramide. Sphingomyelin has a higher affinity for free cholesterol than do other phospholipids in the cell membrane. Hydrolysis of sphingomyelin to ceramide and phosphocholine impacts cellular cholesterol 
homeostasis and gene transcription by 2 different mechanisms. Ceramid is a potent inhibitor of SREBP processing, a process that can regulate endoplasmic reticulum-Golgi vesicular transport and two, lower amounts of sphingomyelin result in a decreased ability to solubilize free cholesterol, which results in intracellular displacement of cholesterol and a consequent decrease in SREBP-mediated gene transcription [36].

Interestingly, in laying hens, dietary DHA as DHA oil was not effective on the expression of SREBP-1 gene in liver [7,9]. It has been speculated that in the laying hens, the de novo lipogenesis in the liver is genetically high in order to generate yolk [7]. The broilers that consumed control diet showed increased SREBP-1 gene expression after fish oil diet suggesting that due to this diet did not contain any supplemental oil (as unsaturated or saturated fatty acids), therefore, inhibitory effects of unsaturated fatty acid or inducible effects of saturated fatty acid did not exist and these birds expressed respect gene in a medium level. In sampling of 42 day of age, similar to previous period, tallow diet showed higher SREBP-1 gene expression with respect to other diets. But the birds fed corn oil diet as dietary n-6 PUFA source were accompanied to a progressive mechanism and thus and thus they showed elevated SREBP-1 gene expression compared with those fed other diets. In studies has been reported that mRNA expression of the key lipogenic transcription factor, SREBP-1, was inversely related to the concentration of the three potent n-3 PUFA, ALA, EPA and DPA and positively related to n-6 PUFA concentration $[1,3]$.

The findings of a study [27] also suggested that the anti-lipogenic effects of n-3 PUFAs are less potent than the prolipogenic actions of n- 6 fatty acids. These results are supported by researcher that showed higher intake of LA was associated with reduced conversion of ALA to downstream long-chain derivatives [20,23]. With regarding these results are inconsistent with our finding, we can possibly conclude that due to in the end of experimental period (42 day of age), concentration of dietary n-6 PUFA in corn oil was maximum, also it is preventive effects on n-3 PUFAs was more severe and thus derivatives of n-3 PUFAs were less produced and their suppressive effect on SREBP-1 gene expression was decreased.

\section{CONCLUSION}

Dietary various lipid sources had profound effects on serum TG and LDL of broilers. In addition, the birds fed diet containing tallow expressed higher SREBP-1 gene than those fed dietary unsaturated sources.

\section{MANUFACTURERS}

${ }^{1}$ Teknokroma Co. Barcelona, Spain.

${ }^{2}$ Younglin Co. Seoul, South Korea.

${ }^{3}$ Bionik Co. Toronto, Canada.

${ }^{4}$ Biotecnica Instruments SpA. Roma, Italy.

${ }^{5}$ Thermoscientific Co. Ranchburg, NJ, USA.

${ }^{6}$ Fermentas/Life Science/Isogene Co. Washington, DC, USA.

${ }^{7}$ Fermentas/Life Science/Isogene Co. Kuala Lampur, Malaysia.

${ }^{8}$ Applied Biosystems Co. Foster City, CA, USA.

Ethical approval. Use of birds in this study was approved by the local institutional animal ethical committee (Protocol 1716-5-10938; 90-11-15).

Declaration of interest. The authors report no conflict of interests. The authors alone are responsible for the content and writing of the paper.

\section{REFERENCES}

1 Ailhaud G., Massiera F., Weill P., Legrand P., Alessandri J.M. \& Guesnet P. 2006. Temporal changes in dietary fats: role of n-6 polyunsaturated fatty acids in excessive adipose tissue development and relationship to obesity. Progress in Lipid Research. 45: 203-236.

2 Albert C.M., Stampfer M.J. 2002. Blood levels of long-chain N-3 fatty acids and the risk of sudden death. New England Journal of Medicine. 346: 1113-1118.

3 Al-Hasani H. \& Joost H.J. 2005. Nutrition-diet-induced changes in gene expression in white adipose tissue, Best Practice and Research. Clinical Endocrinology and Metabolism. 9: 589-603.

4 Assaf S., Hazard D., Pitel F., Morisson M., Alizadeh M., Gondret F., Diot C., Vignal A., Douaire M. \& Lagarrigue S. 2003. Cloning of cDNA encoding the nuclear form of chicken sterol response element binding protein-2 (SREBP-2), chromosomal localization, and tissue expression of chicken SREBP-1 and -2 genes. Poultry Science. 82: 54-61.

5 Calder P.C. 2005. Polyunsaturated fatty acids and inflammation. Biochemistry Society Translation. 33: 423-427. 
6 Celebi S. \& Utlu N. 2000. Influence of animal and vegetable oil in layer diets on performance and serum lipid profile. International Journal of Poultry Science. 5: 370-373.

7 Cheng C.H., Shen T., Chen W.L. \& Ding S.T. 2004. Effect of dietary algal docosahexaenoic acid oil supplementation on fatty acid deposition and gene expression in laying Leghorn hens. Journal of Agriculture Science. 142: 683-690.

8 Cherian G., Goeger M.P. \& Hermes J.C. 2005. Cardiac and hepatic tissue fatty acid composition of broilers dying due to sudden death syndrome. Poultry Science. 84(5): M10.

9 Chin H.J., Shen T.F., Su H.P. \& Ding S.T. 2006. Schizochytrium limacinum SR21 as a source of docosahexaenoic acid: optimal growth and use as a dietary supplement for laying hens. Journal of Agriculture Science. 57: 13-20.

10 Clarke S.D. 2000. Polyunsaturated fatty acid regulation of gene transcription: a mechanism to improve energy balance and insulin resistance. British Journal of Nutrition. 83: 59-66.

11 Cook M.E., Miller C.C., Park Y. \& Pariza M. 1993. Immune modulation by altered nutrient metabolism: nutritional control of immune-induced growth depression. Poultry Science. 72: 1301-1305.

12 Ding S.T., McNeel R.L. \& Mersmann H.J. 2002. Modulation of adipocyte determination and differentiation-dependent factor 1 by selected polyunsaturated fatty acids. In Vitro Cellular and Developmental Biology-Animal. 38: 352-357.

13 Fan Q., Feng J., Wu S., Specht K. \& She S. 1995. Nutritional evaluation of rice bran oil and a blend with corn oil. Nahrung. 39: 490-496.

14 Folch J., Lees M. \& Sloan-Stanley G.H. 1957. A simple method for the isolation and purification of total lipids from animal tissues. Journal of Biology and Chemistry. 226: 497-507.

15 Griffin H.D., Guo K., Windsor D. \& Butterwith S.C. 1992. Adipose tissue lipogenesis and fat deposition in leaner broiler chickens. Journal of Nutrition. 122: 363-368.

16 Hannah V.C., Ou J., Luong A., Goldstein J.L. \& Brown M.S. 2001. Unsaturated fatty acids down-regulate SREBP isoforms 1a and 1c by two mechanisms in HEK-293 cells. Journal of Biology and Chemistry. 276: 4365-4372.

17 Harris W.S. 1989. Fish oils and plasma lipid and lipoprotein metabolism in humans. Journal of Lipid Research. 30 : 785-807.

18 Hassan H.M., Guo H.C., Jin H.C. \& Galal M.Y. 2007. Relation between Abdominal Fat and Serum Cholesterol, Triglycerides, and Lipoprotein Concentrations in Chicken Breeds. Turkish Journal of Veterinary and Animal Sciences. 31: 375-379.

19 Heinze C.R., Hawkins M.G., Gillies L.A., Wu X., Walzem R.L., German J.B. \& Klasing K.C. 2012. Effect of dietary omega-3 fatty acids on red blood cell lipid composition and plasma metabolites in the cockatiel, Nymphicus hollandicus. Journal of Animal Science. 90: 3068-3079.

20 Hibbeln J.R., Nieminen L.R.G., Blasbalg T.L., Riggs J.A. \& Lands W.E.M. 2006. Healthy intakes of n-3 and n-6 fatty acids: estimations considering worldwide diversity. American Journal of Clinical Nutrition. 83: 1483-1493.

21 Johnson R.A., Hamilton J.A., Worgall T.S. \& Deckelbaum R.J. 2003. Free fatty acids modulate intermembrane trafficking of cholesterol by increasing lipid mobilities: novel 13C NMR analyses of free cholesterol partitioning. Biochemistry. 42: 1637-16 45.

22 Kew S., Wells S. \& Thies F. 2003. The effect of eicosapentaenoic acid on rat lymphocyte proliferation depends upon its position in dietary triacylglycerols. Journal of Nutrition. 133: 4230-4238.

23 Lands W.E.M., Morris A. \& Libelt B. 1990. Quantitative effects of dietary polyunsaturated fats on the composition of fatty acids in rat tissues. Lipids. 25: 505-516.

24 Legrand P., Mallard J., Bernard-Griffiths M.A., Douaire M. \& Lemrchal P. 1987. Hepatic lipogenesis in genetically lean and fat chickens: In vitro studies. Comparative Biochemistry and Physiology. 87: 789-792.

25 Lochsen T., Ormstad H., Braud H., Brodal B., Christiansen E.N. \& Osmundsen H. 1997. Effects of fish oil and n-3 fatty acids on the regulation of $\Delta 9$ fatty acid desaturase mRNA and activity in rat liver. Journal of Nutrition and Biochemistry. 8: 408-413.

26 Madsen L., Rustan A.C., Vaagenes H., Berge K., Dyroy E. \& Berge R.K. 1999. Eicosapentaenoic and docosahexaenoic acid affect mitochondrial and peroxisomal fatty acid oxidation in relation to substrate preference. Lipids. 34: 951-963.

27 Muhlhausler B.S., Cook-Johnson R., James M., Miljkovic D., Duthoit E. \& Gibson R. 2010. Opposing effects of omega-3 and omega- 6 long chain polyunsaturated fatty acids on the expression of lipogenic genes in omental and retroperitoneal adipose depots in the rat. Journal of Nutrition and Metabolism. 10: 927836-927839.

28 Ntambi J.M. 1991. Dietary regulation of stearoyl-CoA desaturase I gene expression in mouse liver. Journal of Biology and Chemistry. 267: 10925-10930. 
29 Qi K., Al-Haideri M., Seo T., Carpentier Y.A. \& Deckelbaum R.J. 2003. Effects of particle size on blood clearance and tissue uptake of lipid emulsions with different triglyceride compositions. Journal of Parenteral Enteral Nutrition. 27: 58-64.

30 Sanz M., Flores A., Perez De Ayala. \& Lopez-Bote C.J. 1999. Higher lipid accumulation in broilers fed on saturatedfats than in those fed on unsaturated fats. British Poultry Science. 40: 95-101.

31 Sanz M., Lopez-Bote C.J., Menoyo D. \& Bautista J.M. 2000. Abdominal fat deposition and fatty acid synthesis are lower and $\beta$-oxidation is higher in broiler chickens fed diets containing unsaturated rather than saturated fat. Journal of Nutrition. 130: 3034-3037.

32 Schmidt E.B., Varming K., Moller J.M., Bulow P., Madsen P. \& Dyerberg J. 1996. Effect of a very low dose of n-3 fatty acids on monocyte function in healthy humans. Scandinavian Journal of Clinical Investigation. 56: 87-92.

33 Seo T., Blaner W.S. \& Deckelbaum R.J. 2005. N-3 fatty acids: molecular approaches to optimal biological outcomes. Current Opinion in Lipidology. 16: 11-18.

34 Shimano H. 2001. Sterol regulatory element-binding proteins (SREBPs): transcriptional regulators of lipid synthetic genes. Progress in Lipid Research. 40: 439-452.

35 Thewke D.P., Panini S.R. \& Sinensky M. 1998. Oleate potentiates oxysterol inhibition of transcription from sterol regulatory element-1 regulated promoters and maturation of sterol regulatory element-binding proteins. Journal of Biology and Chemistry. 273: 21402-21407.

36 Worgall T.S., Sturley S.L., Seo T., Osborne T.F. \& Deckelbaum R.J. 1998. Polyunsaturated fatty acids decrease expression of promoters with sterol regulatory elements by decreasing levels of mature sterol regulatory elementbinding protein. Journal of Biology and Chemistry. 273: 25537-25540.

37 Worgall T.S., Johnson R.A., Seo T., Gierens H. \& Deckelbaum R.J. 2002. Unsaturated fatty acid-mediated decreases in sterol regulatory element-mediated gene transcription are linked to cellular sphingolipid metabolism. Journal of Biology and Chemistry. 277: 3878-3885. 